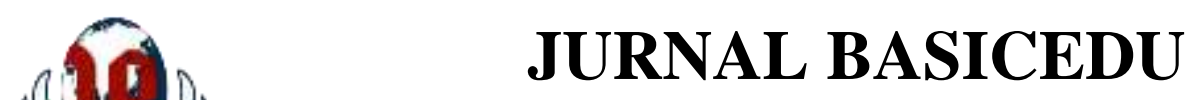

Volume 5 Nomor 6 Tahun 2021 Halaman 5126 - 5132

Research \& Learning in Elementary Education https://jbasic.org/index.php/basicedu

\title{
Primary School Teachers' Continuing Professional Development (CPD) : Teachers' Reflection of Expectation and Reality
}

\author{
Okky Leo Agusta ${ }^{1 凶}$, Muhammad Kristiawan ${ }^{2}$ \\ Universitas Sriwijaya, Indonesia ${ }^{1}$ \\ Universitas Bengkulu, Indonesia ${ }^{2}$ \\ E-mail: okkyprop@ gmail.com ${ }^{1}$, $\underline{\text { muhammadkristiawan@unib.ac.id }}^{2}$
}

\begin{abstract}
Abstrak
Kualitas guru memainkan peran penting dalam peningkatan kualitas pendidikan. Tulisan ini bertujuan untuk menggambarkan refleksi harapan dan kenyataan dari konsep dan pelaksanaan kegiatan PKB guru SD di Lubuklinggau, Sumatera Selatan, Indonesia. Metode kualitatif dengan desain studi kasus digunakan dalam penelitian ini. Kuesioner, wawancara mendalam, dan dokumentasi digunakan dalam pengumpulan data. Hasil penelitian menunjukkan bahwa guru umumnya mengikuti KKG, In House Training (IHT), dan menjadi peserta dalam kegiatan ilmiah seperti seminar dan lokakarya dalam kegiatan pengembangan diri. Selain itu, kurangnya kemampuan guru dalam menulis akademik serta kurangnya akses dalam publikasi ilmiah menjadi kendala guru dalam melaksanakan publikasi ilmiah. Selain itu, keterbatasan dana dan kendala keluarga merupakan hambatan yang umum untuk berpartisipasi dalam kegiatan PKB.
\end{abstract}

Kata Kunci: Pengembangan Keprofesian Berkelanjutan, Guru Sekolah Dasar.

Abstract

Teachers' quality plays a paramount role in improvement of quality of education. The purpose of this paper is to portray the reflection of expectation and reality from the concept and the implementation CPD activities of primary school teachers in Lubuklinggau, South Sumatera, Indonesia. A qualitative method employed a case study design was used in this study. Questionnaire, in-depth interview, and documentation were used in collecting the data. The result indicated that teachers commonly participated in KKG, In House Training (IHT), and becoming participant in scientific activities such as seminars and workshops in self-development activities. In addition, teachers' lack of ability as well as lack of access in scientific publications in academic writing was problem of teacher in actuating scientific publications. Futhermore, limited fund and family constrains were common barrier in participating CPD activities.

Keywords: Continuing Professional Development, Primary School Teacher.

Copyright (c) 2021 Okky Leo Agusta, Muhammad Kristiawan

Corresponding author :

Email : okkyprop@gmail.com

DOI : https://doi.org/10.31004/basicedu.v5i6.1593 
5127 Primary School Teachers' Continuing Professional Development (CPD) : Teachers' Reflection of Expectation and Reality - Okky Leo Agusta, Muhammad Kristiawan

DOI: https://doi.org/10.31004/basicedu.v5i6.1593

\section{INTRODUCTION}

Professional development is any attempt to increase teachers' professional knowledge both during and after the initial preparatory stages in adaptating of new skill and updating the previous beliefs to face the development of the world (Alexandrou, 2021). Professional learning is the key component to improving professional practice and embedding fresh perspectives into daily work and behaviors. While most content has remained consistent throughout time, instructional design, educational policy, and classroom tools and structures have been in constant motion (Brown \& Gilbert, 2021).However, it is believed that professional development consists of career-building activities that are undertaken by practitioners after they complete their teacher training (Merliza \& Retnawati, 2018). A way to ensure high quality teachers is through effective Continuing Professional Development (CPD) for teachers. Teachers face challenges because of school environments. They tend to teach their students independently from their colleagues. Sometimes teachers especially novices become overwhelmed by school bureaucracy demands, and if teachers do not receive insightful feedback or regular supervision, they might become frustrated and less effective . Therefore, professional development activities can solve some of these problematic issues (Siregar, 2018).

Primary education is the cornerstone of formal education around the world. It is the connecting thread between higher levels of learning, instilling in young minds the necessary skills, experiences, and knowledge for a more difficult and higher academic pursuit. The art and act of writing, reading, and the acquisition of necessary skills are all part of primary education. Attitudes and basic information needed for proper adjustment to society and the world in general are provided (Osiesi Mensah Prince, 2020). Primary school is an excellent first step in developing learners' attitudes, which will allow them to develop their future behavior patterns. Primary schools are in charge of teaching basic communication and computing skills that will serve as the foundation for future learning (Wahyudin, 2019).

The Indonesia Ministry of National Education (2012) published the manual book of CPD. It mentioned that teachers in Indonesia should continuously improve their professional competence. There are three things teachers follow in CPD, namely 1), self-development, the activities include functional training, teacher collective activities and competency enhancement activities, 2), scientific publications, the activities include presentations on scientific forums, scientific publications on research in the field of formal education and also publication of textbooks and teacher guidelines, and 3), innovative work, the activities include the discovery of appropriate technology, the discovery or development of artwork, the creation or modification of teaching tools and the preparation of standard questions. CPD for teacher educators is typically initiated upon entry into the profession and continues as a lifelong learning process. There are two common paths for CPD for teacher educators: programs planned and mandated by external agencies and their own initiatives (Tyagi \& Misra, 2021). professional development can also occur in informal contexts such as discussions among work colleagues, independent reading and research, observations of a colleague's work, or other learning from a peer (Mizell, 2020).

CPD has been implemented by teachers and evaluated by researchers around the world. The study conducted by Oliver Heyward et al (2018) revealed CPD must be as long-life learning for teacher in order to match needs and chellanges in $21^{\text {st }}$ century education. CPD activities should be planned in systematically, practically, and collaboratively. Therefore, CPD activity can gain teachers optimally in improving their professional competence. In line with CPD, Chew (2016) found that CPD activites has been implemented and teachers needs in providing opportunities of every CPD stage. Teachers found difficulties in finding colaboratin in improving their skill and expertise. In addition, CPD activities followed by teacher were only self development activities. Teachers found difficulty in reading and writing scientific journal to reach the scientific publication because of the lackness scentific writing ability (Siregar, 2018). 
5128 Primary School Teachers' Continuing Professional Development (CPD) : Teachers' Reflection of Expectation and Reality - Okky Leo Agusta, Muhammad Kristiawan

DOI: https://doi.org/10.31004/basicedu.v5i6.1593

From the resumes of explanations and studies above, this study portrays Primary School Teachers' Continuing Professional Development (CPD) in expectation from Indonesia Minister of National Education manual book of CPD activities (self-development activities, scientific publication, and innovative works) and reality of implementation CPD activities from primary school teachers in Lubuklinggau, South Sumatera.

\section{METHODOLOGY}

The methodology used in this study was qualitative method employed a case study design. A case study is expected to capture the complexities of a single case, and the methodology for doing so has developed within the social sciences (Ebneyamini \& Sadeghi Moghadam, 2018). The data collected through questionnaire, in-depth interview, and documentation. The questionnaire was to find out the activities of CPD followed by primary school teachers, in-depth interview was to investigate primary school teachers' perceptions about CPD activities, and documentation was to be evidence of what primary school teachers reveal in questionnaire and interview. The participants in this study were 12 teachers from 6 primary schools. In order to establish the trustworthiness, triangulation was used to justify the findings from questionnaire, indept-interview, and documentation. Triangulation was to compare different findings from different prepective in order to find the valid information (Heale \& Forbes, 2017).

\section{RESULT AND DISCUSSION}

CPD activities of primary school teachers was revealed by questionnaire. The teacher filled out the questionnaire by giving ticks in CPD activities. The site and the teacher were presented by PS (Primary school) and $\mathrm{T}$ (teacher).

Table 1. CPD Activities of Primary School Teachers

\begin{tabular}{|c|c|c|c|c|c|c|c|c|c|c|c|c|c|c|}
\hline \multirow[t]{4}{*}{ No } & \multirow{4}{*}{$\begin{array}{l}\text { Components } \\
\text { of CPD }\end{array}$} & \multirow[t]{3}{*}{ Activities } & \multicolumn{2}{|c|}{ PS1 } & \multicolumn{2}{|c|}{ PS2 } & \multicolumn{2}{|c|}{ PS3 } & \multicolumn{2}{|c|}{ PS4 } & \multicolumn{2}{|c|}{ PS5 } & \multicolumn{2}{|c|}{ PS6 } \\
\hline & & & $\mathbf{T}$ & $\mathbf{T}$ & $\mathbf{T}$ & $\mathbf{T}$ & $\mathbf{T}$ & $\mathbf{T}$ & $\mathbf{T}$ & $\mathbf{T}$ & $\mathbf{T}$ & $\mathbf{T}$ & $\mathbf{T}$ & $\mathbf{T}$ \\
\hline & & & & 2 & 3 & 4 & 5 & 6 & 7 & 8 & 9 & 1 & 1 & 1 \\
\hline & & PPG & 1 & & & & & & $\sqrt{1}$ & 1 & & $\mathbf{0}$ & 1 & 2 \\
\hline \multirow[b]{2}{*}{1} & & $\begin{array}{l}\text { PPG } \\
\text { KKG (Teacher Groun) }\end{array}$ & $\mathrm{V}$ & - & - & - & - & - & $\mathrm{V}$ & v & $=$ & - & $\mathrm{V}$ & - \\
\hline & $\begin{array}{l}\text { Self- } \\
\text { Developme } \\
\mathrm{nt}\end{array}$ & $\begin{array}{l}\text { In House Training (IHT) } \\
\text { A participant in scientific } \\
\text { activities (online/offline) }\end{array}$ & $\sqrt{ }$ & $\sqrt{ }$ & $\sqrt{ }$ & $\sqrt{ }$ & $\sqrt{ }$ & $\sqrt{ }$ & $\sqrt{ }$ & $\sqrt{ }$ & $\sqrt{ }$ & $\sqrt{ }$ & $\sqrt{ }$ & $\sqrt{ }$ \\
\hline \multirow{5}{*}{2} & \multirow{5}{*}{$\begin{array}{l}\text { Scientific } \\
\text { Publications }\end{array}$} & $\begin{array}{l}\text { Becoming } \\
\text { transmitter/interviewee in } \\
\text { seminar }\end{array}$ & $\sqrt{ }$ & - & - & - & - & - & $\sqrt{ }$ & - & - & - & $\sqrt{ }$ & $\sqrt{ }$ \\
\hline & & $\begin{array}{l}\text { Publishing written research } \\
\text { results, scientific review } \\
\text { papers, scientific articles in } \\
\text { education }\end{array}$ & $\sqrt{ }$ & - & - & - & - & - & $\sqrt{ }$ & - & - & - & $\sqrt{ }$ & $\sqrt{ }$ \\
\hline & & $\begin{array}{l}\text { Publishing textbook, } \\
\text { module/dictate of learning in } \\
\text { a semester, books in } \\
\text { education, translation works, } \\
\text { and/or teacher manual }\end{array}$ & $\sqrt{ }$ & - & - & - & - & - & $\sqrt{ }$ & - & - & - & - & $\sqrt{ }$ \\
\hline & & $\begin{array}{lll}\text { Inventing of efficient } \\
\text { technology }\end{array}$ & $\sqrt{ }$ & - & - & - & - & - & - & - & - & - & - & $\sqrt{ }$ \\
\hline & & Inventing/developing & - & - & - & - & - & - & - & - & - & - & - & - \\
\hline
\end{tabular}


5129 Primary School Teachers' Continuing Professional Development (CPD) : Teachers' Reflection of Expectation and Reality - Okky Leo Agusta, Muhammad Kristiawan

DOI: https://doi.org/10.31004/basicedu.v5i6.1593

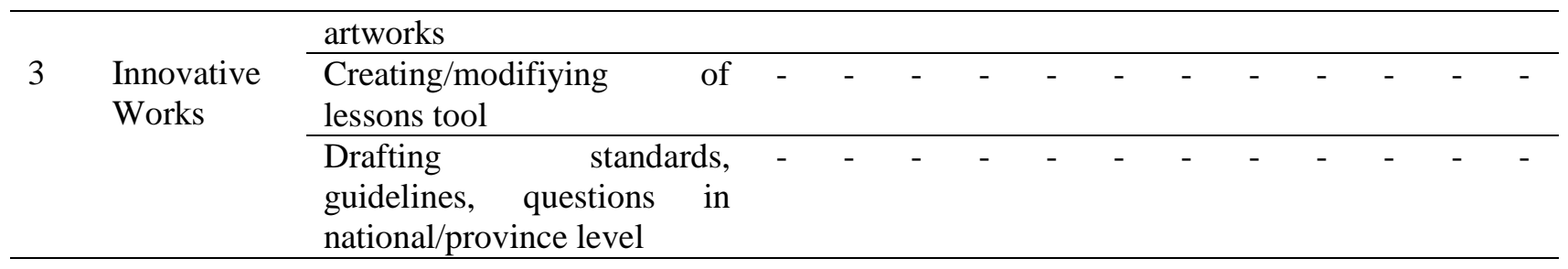

Table 1 showed that twelve primary school teachers had undertaken self-development activities. They had partcipated in KKG (teacher group), In House Training (IHT), and in scientific activities dominantly online seminar and workshop. In Pandemic Covid-19, KKG was not fully active and teachers participated online learning/seminar and workshop. From the twelve teachers, it was only four teachers who had undertaken PPG in-service teacher program.

From the interview, teachers often explained the online learning/ seminar process and PPG in-service program system. one of the teachers stated as indicated in the following interview excerpt:

[...] KKG (teacher group) in Pandemic Covid-19 is not fully active but we are directed from KKG committee in having meeting online, joining seminar online, and discussing online. We think online seminar and workshop are not effective for us because it finds difficulty in understanding materials from the speakers and some seminars are very expensive. In addition, online seminar and workshop are taken by outcam mode and we do another something else unless we will get certificate. PPG inservice program takes long time for us in waiting list. Therefore, we are hopeless and we don't when we will be participated in that program $[\ldots]$ (T13)

In interview process, some teachers had same perceptions of KKG and PPG in-service program. They taugh that KKG asked teachers to participate in online seminar and workshop but the activities were not effective for them with virtual communication and they taugh that they will be convenience if the seminars or worshops were offline. In the other hand, some teachers deliberated some of online seminar and workshop were expensive for them and school did not accommodate them to participate in that seminars and workshops. In term of scientific publications, it was four teachers who were actively becoming transmitter/interviewee in seminar and publising textbooks. The other teachers revealed reasons why they didn't actively participate in scientific publication in following interview excerpt:

[...] We feel that scientific publications are not easy to do. We confuse from where we should start to read and write $[\ldots]$ (T9)

Based on the statements above, the teachers had gap in actuating their willing to do scientific publication with their ability in academic writing. They confuse with whom they should discuss about scientific publication because KKG activities are rarely in discussing of academic wirting. Teachers said that they had their academic writing when they wrote their theses. This condition could be infer that less of facilitator and information made teachers found difficult in actuating scientific publication. In innovative works components, the teacher faced the same problems as in following interview excerpt:

[...] To do innovative works for us is time consuming. There are many things that should be done. We are in a whole-day school and we have family at home. When teaching can be separated from administration works, it is chance for us to learn more in developing innovative work.. [...] (T5) 
5130 Primary School Teachers' Continuing Professional Development (CPD) : Teachers' Reflection of Expectation and Reality - Okky Leo Agusta, Muhammad Kristiawan

DOI: https://doi.org/10.31004/basicedu.v5i6.1593

Innovative works for teacher was stuck because of time constrain. Teachers taugh they should read, learn, and develop innovative works but they do not have enough time for their duty as teacher and their duty as parents. Two of twelve teachers in this study always participated in developing innovative works. They revealed that they had got experiences in developing innovative works when they pursued their master degree (S2). The teacher perceptions above remained that teaching was not a simple profession. Teacher should have deliberation between their duty in teaching and their family time. Along the same line, teacher's work in the other side, innovative behavior plays a very crucial role in enhancing the performance of schools and society and it should be the main concern of teachers (Hosseini \& Haghighi Shirazi, 2021).

Teachers' professional skills include the ability to plan, implement, and evaluate ongoing learning teacher training programs to improve teacher competency and performance in schools. The teacher is a blend of personal, scientific, technological, social, and spiritual competencies that contribute to the teacher's professional competency standards, which include material mastery, student understanding, educated learning, personal development, and professionalism (Prihidayanti et al., 2019). This study found many aspects affected teachers CPD activities especially in Cov-19 Pandemic. Teacher should adapt with this situation not only the innovation of teaching process but also the adaption in professional development. The adaptation was needed to move the ways of communication from direct communication to virtual communication (Nugraha \& Maulida, 2021). In term of in-service PPG program, PPG is one of teacher profesional development program inisiated by government. Teachers upgrade their ability in academic ability and profesional services in education. Easy access in participating PPG will build teachers' profesional development in providing better teaching and learning process (Arifa \& Prayitno, 2019).

Futhermore, teachers' ability in academic writing was still low. Academic writing will increase writers' knowledge, critical thinking, and career development (Ntereke \& Ramoroka, 2015). Primary school teachers in this study needed training and guidance in implementing academic writing. KKG should take stakeholders as speakers and guidances in academic writing workshop continuously. Access in publishing academic writing in journal was also needed in order to support, motivate, and appreciate teachers in writing. The other benefits for teachers in academic writing, they can share their experiences and methods in teaching and learning process through their writing. The continous writing will make teachers update with critical education development.

Time constrain became obstruction in CPD activities. CPD activities tooks a lot of time for teachers. They should maintance their time in spending teaching at school and family time at home. Activities that take mothers away from the home, in this case, school, are less important than their responsibilities at home (Kayumova et al., 2015). In contrast, male teachers had more interest in developing their personal ability rather than female teacher (Badri et al., 2016). In personal problem of teaching schedule, it was complex matter that should be faced by teachers.

\section{CONCLUSION}

From the result and discussion above, it could be concluded that the primary school teachers in Lubuklinggau had followed CPD activities especially in self-development activities. Teachers commonly participated in KKG, In House Training (IHT), and becoming participant in scientific activities such as seminars and workshops, but some teachers revealed online seminars and workshops were not effective for them. In addition, teachers' lack of ability in academic writing was problem of teacher in actuating scientific publications as well as lack of access in scientific publications. Futhermore, limited fund and family constrains were common barrier in participating CPD activities. 
5131 Primary School Teachers' Continuing Professional Development (CPD) : Teachers' Reflection of Expectation and Reality - Okky Leo Agusta, Muhammad Kristiawan

DOI: https://doi.org/10.31004/basicedu.v5i6.1593

\section{REFERENCES}

Alexandrou, A. (2021). Professional Learning And Development-Change, Conceptualisation, Innovation And Opportunities. Professional Development In Education, 47(5), 725-728. Https://Doi.Org/10.1080/19415257.2021.1966588

Arifa, F. N., \& Prayitno, U. S. (2019). Peningkatan Kualitas Pendidikan: Program Pendidikan Profesi Guru Prajabatan Dalam Pemenuhan Kebutuhan Guru Profesional Di Indonesia. Aspirasi: Jurnal MasalahMasalah Sosial, 10(1), 1-17. Https://Doi.Org/10.46807/Aspirasi.V10i1.1229

Badri, M., Alnuaimi, A., Mohaidat, J., Yang, G., \& Al Rashedi, A. (2016). Perception Of Teachers' Professional Development Needs, Impacts, And Barriers: The Abu Dhabi Case. SAGE Open, 6(3). Https://Doi.Org/10.1177/2158244016662901

Brown, E., \& Gilbert, K. F. (N.D.). Professional Growth Continuum.

Chew, L. C. (2016). Teacher Training And Continuing Professional Development: The Singapore Model. Prosiding ICTTE FKIP UNS 2015, 1(1), 165-171.

Ebneyamini, S., \& Sadeghi Moghadam, M. R. (2018). Toward Developing A Framework For Conducting Case Study Research. International Journal of Qualitative Methods, 17(1), 1-11. Https://Doi.Org/10.1177/1609406918817954

Education, I. M. Of N. (2012). Pengembangan Keprofesian Berkelanjutan.

Heale, R., \& Forbes, D. (2013). Understanding Triangulation In Research. Evidence-Based Nursing, 16(4), 98. Https://Doi.Org/10.1136/Eb-2013-101494

Hosseini, S., \& Haghighi Shirazi, Z. R. (2021). Towards Teacher Innovative Work Behavior: A Conceptual Model. Cogent Education, 8(1). Https://Doi.Org/10.1080/2331186X.2020.1869364

Kayumova, S., Karsli, E., Allexsaht-Snider, M., \& Buxton, C. (2015). Latina Mothers And Daughters: Ways Of Knowing, Being, And Becoming In The Context Of Bilingual Family Science Workshops. Anthropology And Education Quarterly, 46(3), 260-276. Https://Doi.Org/10.1111/Aeq.12106

Merliza, P., \& Retnawati, H. (2018). Continuing Professional Development (CPD) For Junior High School Mathematics Teachers: An Evaluation Study. Research And Evaluation In Education, 4(1), 79-93. Https://Doi.Org/10.21831/Reid.V4i1.18757

Mizell, H. (2010). PROFESSIONAL Why Matters. Learningforward.Org, 28.

Ntereke, B., \& Ramoroka, B. (2015). Effectiveness Of Academic Writing Activities And Instruction In An Academic Literacy Writing Course At The University Of Botswana. Journal Of Pedagogic Development, 5(3), 45-56.

Nugraha, M. A., \& Maulida, I. (2021). English Teacher Professional Development To Education 4 . 0 During The Covid-19 Pandemic. 9(2), 445-452.

Oliver Heyward, M., Selfi Cholifah, P., \& Sakinah Nuraini, N. L. (2018). Continuous Professional Development In The Primary School. November. Https://Doi.Org/10.2991/Ecpe-18.2018.28

Osiesi Mensah Prince. (2020). The Import Of Professional Development Programmes For Primary School Teachers In Nigeria. International Journal On Integrated Education, 3(7), 111-118. Https://Doi.Org/10.31149/Ijie.V3i7.507

Prihidayanti, Y., Florentinus, T. S., \& ... (2019). ... Education And Training Program Of Continuous Professional Development Program Of In On In Modes On Pedagogical And Professional Competence Of Teachers In ... Innovative Journal Of ..., 8(2), 90-97. Https://Journal.Unnes.Ac.Id/Sju/Index.Php/Ujet/Article/View/33091

Siregar, H. (2018). Continuing Professional Development ( CPD ) For Teachers Of English. Lingua, Jurnal Bahasa \& Sastra, 18(2), 134-140. 
5132 Primary School Teachers' Continuing Professional Development (CPD) : Teachers' Reflection of Expectation and Reality - Okky Leo Agusta, Muhammad Kristiawan DOI: https://doi.org/10.31004/basicedu.v5i6.1593

Tyagi, C., \& Misra, P. K. (2021). Continuing Professional Development Of Teacher Educators: Challenges And Initiatives. Shanlax International Journal of Education, 9(2), 117-126. Https://Doi.Org/10.34293/Education.V9i2.3634

Wahyudin, J. \& D. (2019). How Important Are Today's Teacher Development Program Contents For Primary School Teacher? Jurnal Penelitian Ilmu Pendidikan, 12(1), 55-62. 